\title{
Significance of fossilized microbes from the Cambrian stromatolites in the Tarim Basin, Northwest China
}

\author{
YOU XueLian ${ }^{1,2,3^{*}}$, SUN Shu ${ }^{2} \&$ ZHU JingQuan ${ }^{2}$ \\ ${ }^{1}$ School of Ocean Sciences, China University of Geosciences, Beijing 100083, China; \\ ${ }^{2}$ Institute of Geology and Geophysics, Chinese Academy of Sciences, Beijing 100029, China; \\ ${ }^{3}$ Max-Planck Institute for Marine Microbiology, Bremen D-28359, Germany
}

Received November 16, 2013; accepted March 20, 2014; published online October 10, 2014

\begin{abstract}
Samples of the Cambrian microbial dolomites were collected from Penglaiba section, a well-exposed stratigraphic section in the northwestern area of the Tarim Basin. This study provides an analogue for mediated dolomites that can precipitate in microbial mats and biofilms. The Cambrian stromatolitic dolomites were studied using high-resolution scanning electron microscopy. The results are as follows: (1) dolomites with $50 \mathrm{~nm}$ to $100 \mathrm{~nm}$ spherical nanostructures are aggregated into minerals of larger sphericities; (2) nanospherical dolomites of $50 \mathrm{~nm}$ to $170 \mathrm{~nm}$ diameter are densely arranged as dumbbell-shaped or chained aggregates; (3) silicified filaments, as well as dumbbell-shaped and chain arrangements, are preserved as important microstructures. On the basis of sedimentological, compositional, geochemical, and petrographic data, the microstructures were interpreted as nanoglobules that function as bacteria in the nucleation and filament mineralization stages. The microstructures function as such because they are wrapped in extracellular polymeric substance (EPS) or mucus and mineralized fossils. Silicification accounts for the exceptional preservation of microbial mat structures, including biofilms, as well as filamentous and coccoid microbes. In addition, EPS process is capable of binding different elements, with preference for $\mathrm{Si}, \mathrm{Mg}$, and $\mathrm{Ca}$. Such suitable composition favors microbe mineralization and dolomite nucleation on organic substrates. These microscopic structures suggest bacterial mineralization and provide visual evidence for the origin of microbial dolomites.
\end{abstract}

Cambrian, stromatolite, fossilized microbe, mediated dolomite

Citation: You X L, Sun S, Zhu J Q. 2014. Significance of fossilized microbes from the Cambrian stromatolites in the Tarim Basin, Northwest China. Science China: Earth Sciences, 57: 2901-2913, doi: 10.1007/s11430-014-4935-z

Sedimentologists have long focused on the link between microorganisms and carbonates. In ancient and modern sedimentary environments, as well as in microbial culture experiments, microorganisms (especially bacteria) have been found highly related to the carbonate deposition process (Buczynski and Chafetz, 1991; Schultze-Lam et al., 1996; Douglas and Beveridge, 1998; Castanier et al., 1999; Bosak and Newman, 2003; Duprza and Visscher, 2005; Visscher and Stolz, 2005). New research possibilities for the study of the "Dolomite Problem" enigma (Fairbridge, 1957; Lipp-

*Corresponding author (email: youxuelian@cugb.edu.cn; youxuelian007@gmail.com) mann, 1973; McKenzie and Vasconcelos, 2009; Sun, 2005) have arisen because of the introduction of microbial factors into such investigations (Vasconcelos et al., 1995; Vasconcelos and McKenzie, 1997; Warthmann et al., 2000). Microbial mediated dolomites can form in some modern hypersaline depositional environments, such as the coastal lagoon Lagoa Vermelha in Rio de Janeiro, Brazil (Vasconcelos and McKenzie, 1997), lakes of the Coorong region in South Australia (Wright, 1999), and the Qinghai Lake in the Tibetan Plateau, Northwest China (Deng et al., 2010). Culture experiments have shown that sulfate-reducing bacteria, methanogens, and moderately halophilic aerobic bacteria 
can mediate the formation of primary dolomites under the Earth's surface (Vasconcelos et al. 1995; Vasconcelos and McKenzie 1997; van Lith et al. 2003a, 2003b; Roberts et al. 2004; Wright and Wacey, 2005; Sánchez-Román et al., 2008, 2009, 2011; Kenward et al., 2009). The Desulfobulbus mediterraneus strain mediated primary dolomite formation at very low temperatures $\left(21^{\circ} \mathrm{C}\right)$ in seawater conditions (Krause et al., 2012). Experiments on modern environments and laboratory studies have documented the important role of microorganisms in mediating dolomite formation; such studies support the hypothesis that dolomite formation in geological periods is characterized by recrystallization during diagenesis (Tucker and Wright, 1990). Therefore, the traces or biosignatures of microbes from ancient dolomites are difficult to determine. Nevertheless, similar to stoichiometric dolomites and the dolomites that formed in the Coorong Lake, South Australia (Wright, 1999), some dolomites exhibit a diagenetic trend in terms of burial depth (Vasconcelos and McKenzie, 1997). Based on observations of the microstructure characteristics in ancient dolomite by high-resolution scanning electron microscopy to determine the link among microbial dolomites in geological record, the formation of dolomite in modern environments, and culture experiments, it maybe is a significant approach for elucidating the origin of dolomites (You et al., 2011).

In this study, the well-exposed stratigraphic Penglaiba section (Kalpin areas) in the northwestern region of the Tarim Basin was investigated. The region is composed of the Cambrian strata. Previous studies have been conducted on the microfacies (Liu et al., 2012), as well as the geochemical and isotopic (carbon, oxygen, and strontium) compositions of the Cambrian Series 2 and 3 in the Penglaiba section (Wang et al., 2011). Geochemical data on the Upper Cambrian stromatolites have also been reported (Xie et al., 2009). The current work aimed to determine the microbial origin of the dolomites that formed in the Cambrian stromatolites of the Penglaiba section by high-resolution scanning electron microscopy and other techniques. We also identified the mechanism and process of dolomite formation in this region.

\section{Geological setting}

The Tarim Basin developed from a continental crust composed of the Proterozoic metamorphic rocks into a Mesozoic and Cenozoic foreland basin (Jia, 1997). It is surrounded by the Kunlun and Tianshan tectonic zones to the west, north, and south. The uplifts and depressions in the northwestern area of the basin are shown in Figure 1 (Jia, 1997). As the figure shows, several wells reach the Cambrian strata in the basin: The Awatage Formation (which has a typical red color) can be observed in the Yaha 5 and Yingmai 7 wells of the Tabei area; the Tazhong uplift can be observed in the
Tacan 1 well; and the Bachu uplift is evident in the Fang 1 well (Chen et al., 2008). However, typical stromatolites are rarely found in the drilling cores. The outcrops are regarded as appropriate for research on stromatolites, especially those in the Penglaiba section (Figure 1) (Jia, 1997; You et al., 2013; Wang et al., 2011).

We focused on the Middle Cambrian and Upper Cambrian strata as we investigated the stratigraphy and lithology of the Penglaiba section (Figure 2). The Middle Cambrian strata were divided into two formations: The Sayilike $\left(\epsilon_{2} s\right)$ and Awatage formations $\left(\epsilon_{2} a\right)$. The latter is composed primarily of typical stromatolites (Figure 3(a)).

The Awatage Formation is composed of micritic and finegrained dolomites with horizontal bedding and cross-bedding structures. These beds are interlayered with centimeter-thick greenish to reddish mudstones, which contain abundant lenticular anhydrite crystals or moulds. The beds are also associated with layers of stromatolitic dolomites that are deposited in the upper region of the Awatage Formation (Figure 3(a)). This formation is a shallow evaporative environment. The overlying Lower Qiulitage Formation is powder dolomite from sheet to medium-bedding with light to dark gray colors. The thickness of the Formation is over 200 meters, and the bottom of the Lower Qiulitage Formation distributes debris beach and tidal flat in the open platform facies (Liu et al., 2012). The lower part of the Lower Qiulitage Formation continuously is up to a maximum of meter-thick cycles, consisting of four or three microfacies. The cycle comprises, from the bottom upwards, sheet-bedded muddy dolomite with light gray color, sheet-bedded powder dolomite in gray, microbial reef dolomite in dark gray (only developed in four microfacies) and dolomitic stromatolites in brown to light gray (Figure 3(b)). The middle and upper parts of the Lower Qiulitage Formation are continuously distributed up to a maximum of meter-thick cycles, consisting of less microfacies than three, which are transformed from beach- tidal flat to restricted platform facies.

\section{Methods and sampling}

After standard petrographic analyses for the Middle and the Upper Cambrian from Penglaiba section under Olympus BX-51, thin sections were prepared for fluorescence microscopy using a Zeiss Axioskop 40A. Scanning electron microscope (SEM) studies were carried out on polished thin sections or fresh broken surfaces. All samples were ultrasonically cleaned with alcohol. Some samples were first etched with dilute hydrochloric acid before ultrasonic cleaning. To ensure that each sample could be used for microanalysis and textural study, two replicate samples were removed from the same position. One sample was carboncoated and the other was gold-coated. A Gatan Model 682 precision etching and coating system (PECS) was used to spatter the gold coating onto the SEM samples and fresh 




Figure 1 Tectonic units of the Tarim Basin and geological units of the study area. Modified after Jia (1997), You et al. (2013) and Wang et al. (2011).

broken surfaces to improve the conductivity. The spattering was carried out by two Penning ion guns trained on a 99.99\% pure gold target. The PECS coating system is designed to slowly deposit electron-transparent amorphous gold coating with a built-in thickness monitor, facilitating a controlled deposition of $0.12 \mathrm{~nm}$ of gold per second and the ion beam is 300 amps. In this way, a $15 \mathrm{~nm}$-thick gold coating was deposited onto all spattered samples. All microstructures and surface morphologies were observed using JEOL JSM-6490 scanning election microscope and Nova ${ }^{\mathrm{TM}}$ NanoSEM 230 field emission scanning election microscope (FESEM). At the same time, semi-quantitative analyses of submicron-sized spots were performed with an energy dispersive $X$-ray (EDX) spectrometer. The SEM/EDX analyses were performed at the State Key Laboratory for Mineral
Deposits Research and the National Laboratory of Solid State Microstructures, Nanjing University.

\section{Petrological characteristics of stromatolitic dolomites}

\subsection{Field characteristics and sedimentary microfacies}

The stromatolitic dolomites are distributed throughout the Middle Cambrian Awatage Formation and the Upper Cambrian Qiulitage Formation. The Penglaiba section was divided into 227 sequences for the Cambrian strata, and 147 sequences for the Awatage and Qiulitage formations. We obtained 12 stromatolite sequences, which are $8.2 \%$ of the total number of sequences in the Middle and Upper Cambrian 


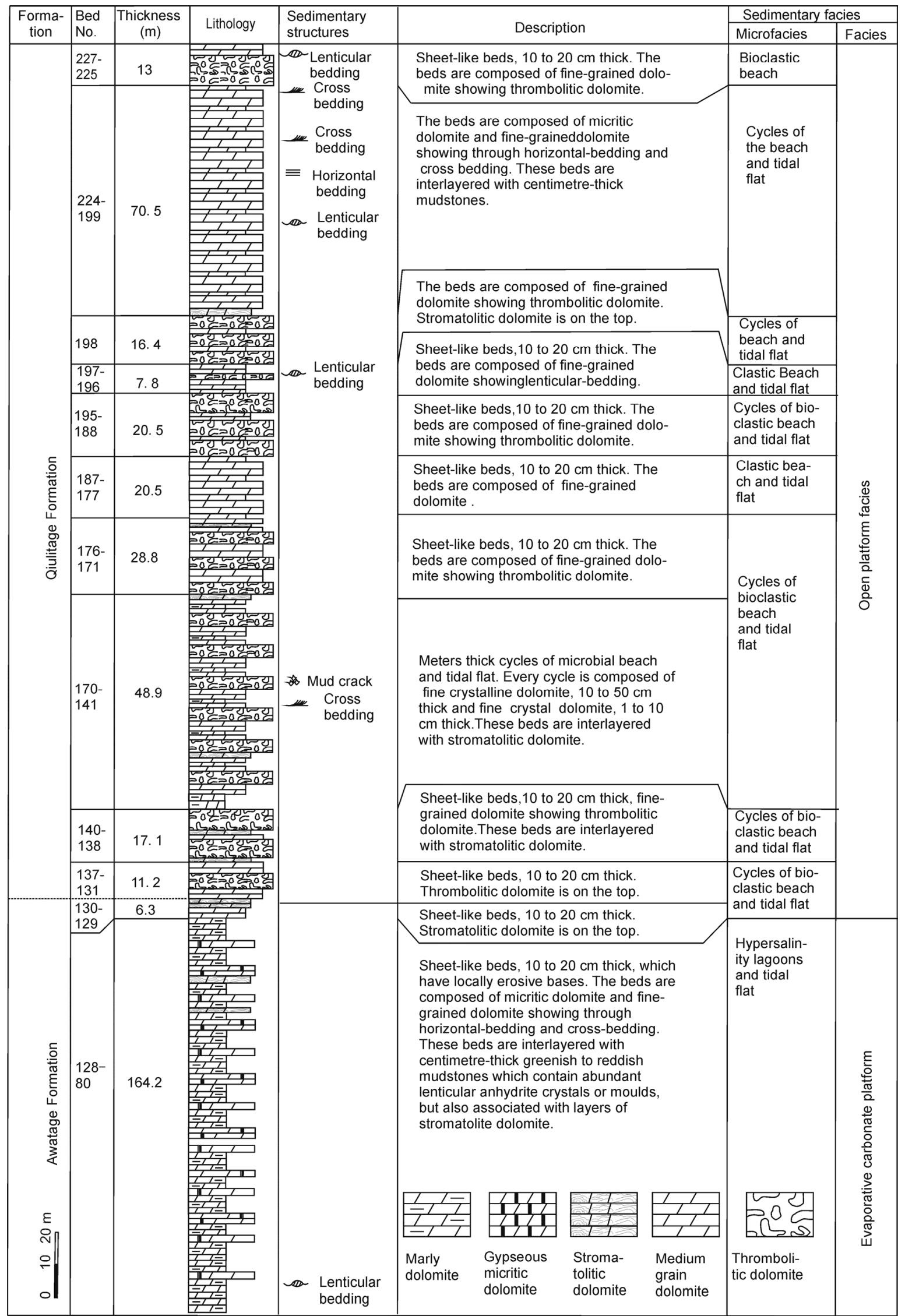

Figure 2 Sedimentary log of dolomite succession in the Middle and Upper Cambrian strata in the Penglaiba section. 
strata. The thickness of the stromatolites is approximately $22.8 \mathrm{~m}$, accounting for $2.8 \%$ of total thickness $(826.3 \mathrm{~m})$.

The outcrops are composed of mostly khaki to brick red stromatolitic dolomites and some light gray stromatolitic dolomites. The morphologies of the stromatolites are characterized by low-relief planar-domal laminations, but some exhibit dome-like morphologies. The maximum thickness of the monolayers of the stromatolites is $91 \mathrm{~cm}$. The stromatolite sequences extend in a stable manner.

The stromatolitic dolomites in the Awatage Formation are associated with sheet bedding of $10-50 \mathrm{~cm}$ thick. These dolomites are micritic types characterized by frequent subaerial exposure surfaces, anhydrite nodules, or gypsum pseudomorphs. The sheet bedding is composed of anhydrite and single bedding is $5-50 \mathrm{~mm}$ thick. Aggregated anhydrite nodules or gypsum pseudomorphs $(2-20 \mathrm{~mm})$ are distributed in laminated micritic dolomites. These features indicate that the stromatolitic dolomites in the Awatage Formation are deposited in evaporated tidal flats or Sabkha (Zhu et al., 2008).

In the Qiulitage Formation, the stromatolites are found in the lower portion of the area, particularly around the boundary between the Awatage and Qiulitage formations. These stromatolites are filled with low-relief planar-domal laminations and domes (Figure 3(b)-(d)). In meter-scale cycles, packstone dolomites are from limestones, which were characterized by high energy and were deposited in beach environments (Zhu et al., 2008). Therefore, the stromatolitic dolomites in the Qiulitage Formation were formed by frequent sea-level fluctuations from tidal flats to beach environments (Zhu et al., 2008).

\subsection{Microscopic characteristics and distribution of organic matter}

The crystals in the well-laminated and micritic dolomites in the stromatolites have a diameter of less than $0.03 \mathrm{~mm}$. Dense laminations are stacked as stromatolitic laminae (Figure 4(a)). Laminae are usually isopachous, even and smooth, and varying from $0.1 \mathrm{~mm}$ to $0.5 \mathrm{~mm}$ in thickness. Stromatolitic laminae consist of alternating layers of dark laminae (d in Figure 4(a)) and light laminae ( 1 in Figure 4(a)). Light laminae, which have a thickness of 120-440 $\mu \mathrm{m}$, are microspar dominated by large fabric-preserving planar subhedral to euhedral dolomite crystals. Assessment by Alizarin red staining indicates that all the samples are almost dominated by dolomites and minimal calcites, and are macrospar that filled the cavity structures during late-stage formation (Figure 4(b)). $X$-ray diffraction (XRD) patterns show that dolomite minerals account for more than $96 \%$ of sample composition, and calcites account for less than $4 \%$. Further observations show the presence of obvious pustules and dark spherical aggregates in the stromatolitic laminae (white arrows in Figure 4), which are primarily dark laminae. Fabric-preserving dark micrites are uniformly very dull or non-luminescent (Figure 4(c), (d)).

The XRD patterns also indicate that the bright orange luminescent zones in the stromatolitic laminae formed in
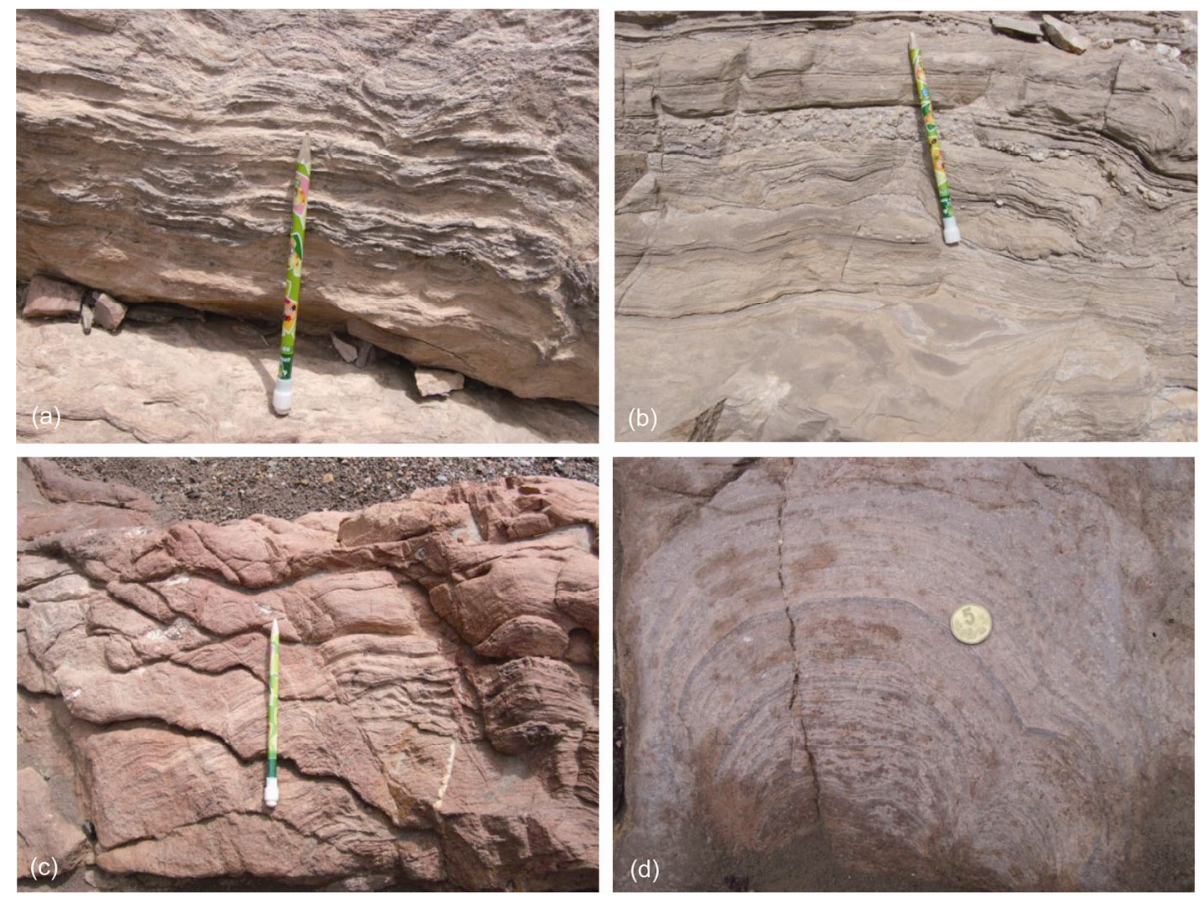

Figure 3 Field images of the stromatolitic dolomites. (a) Stromatolites in the Awatage Formation filled with low-relief planar-domal laminations; (b) low-relief planar-domal laminations in the middle part of Qiulitage Formation; (c), (d) low-relief planar-domal laminations and domes in red colour at the bottom of Qiulitage Formation 

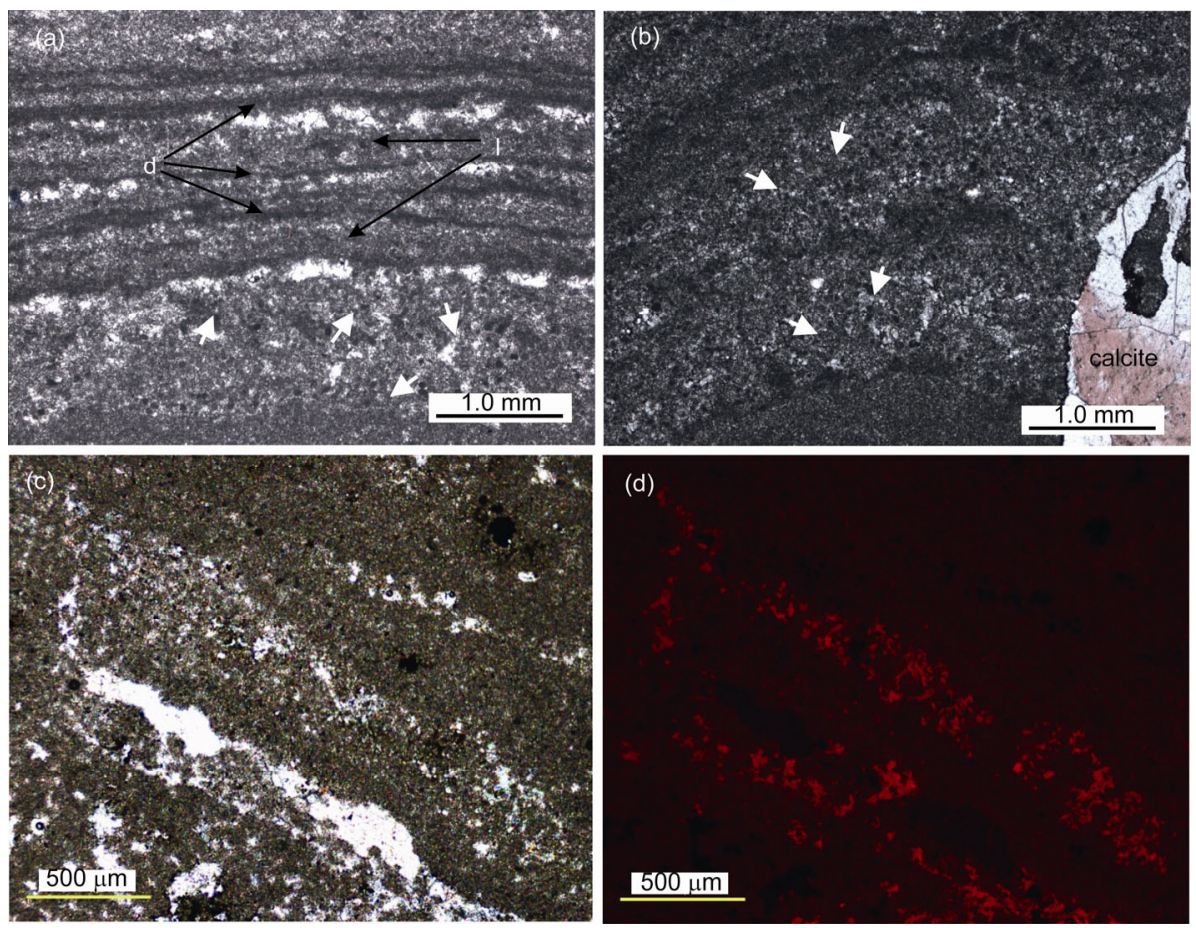

Figure 4 Photomicrographs illustrating the characteristics of stromatolites. (a) Stromatolitic laminae consist of alternating layers of dark laminae "d" and light laminae "l" and pustules and dark spherical aggregates (white arrows); (b) closed to pustules and dark spherical aggregates (white arrows), and sparry calcite in right formed in late diagenesis; (c), (d) fabric-preserving dark micrites in microscopy and the same area is uniformly very dull or non-luminescent.

late diagenesis. Therefore, dark laminations are rarely altered by late diagenesis. However, the dark laminae are strongly fluorescent (Figure 5(a), (b)), indicating that such laminae are rich in organic matter and well-preserved organic material. The spherical dolomitic aggregates that exhibit strong fluorescence (Figure 5(c), (d)) have morphologies
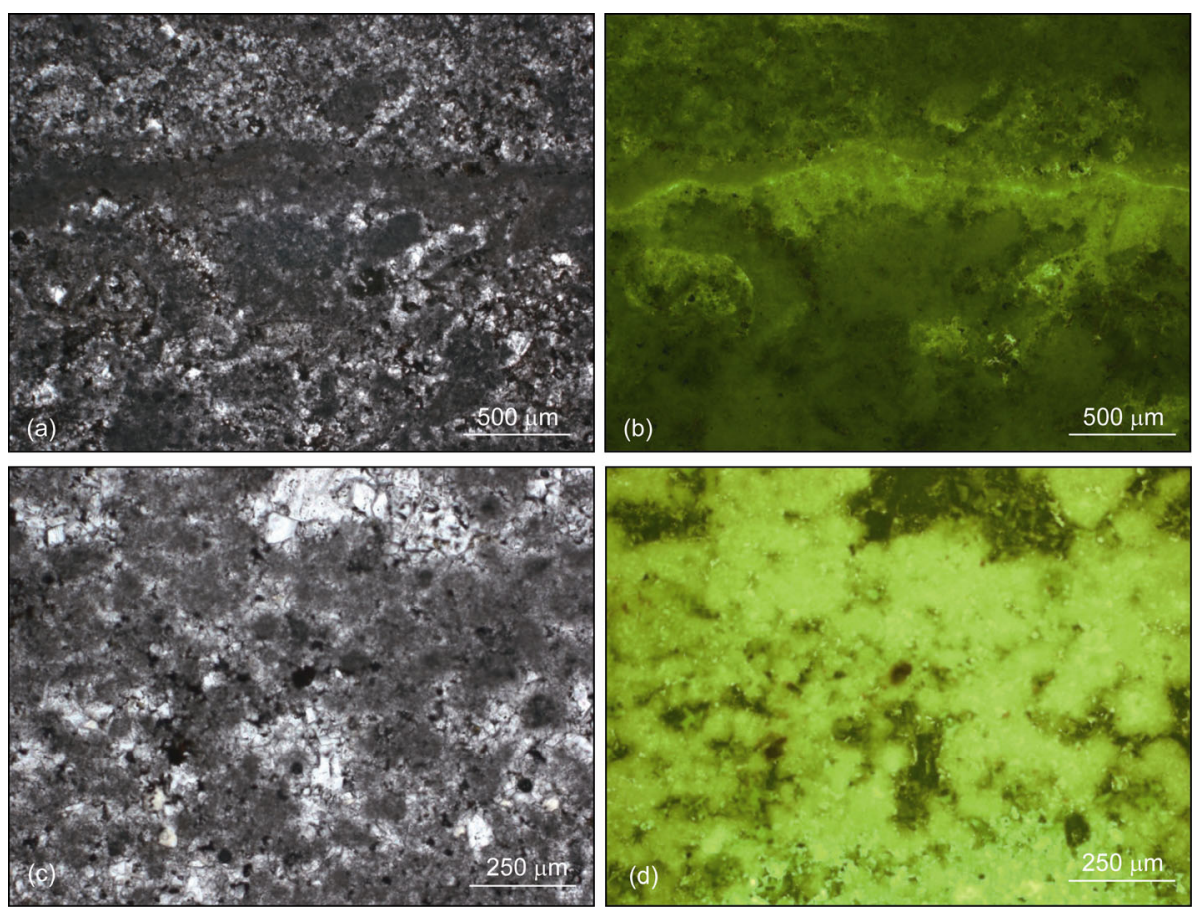

Figure 5 Microscopic photos of stromatolites visualized under transmitted and epifluorescent light. (a) Thin dark laminae in microscopy; (b) the same area strongly fluorescent and rich in organic matter and well-preserved organic material; (c) the spherical dolomitic aggregates in microscopy; (d) the same area strongly fluorescent (Green fluorescent BP $436 / 10 \mathrm{~nm} / \mathrm{LP} 470 \mathrm{~nm}$ ). 
similar to the aggregates shown in Figure 4; the latter may be microorganic residues. On the basis of the chromophores in the morphology and size distribution, these aggregates may be categorized as coccoid cells (probably cyanobacteria).

\section{Microfabrics determined by scanning elec- tron microscopy}

Scanning electron microscopy (SEM) observations of the stromatolitic dolomites show numerous microstructures and microfabrics of micron or nanometer size. They are present on the surface of the micritic dolomites in the dark laminae and sometimes extend across dolomite crystals. One of the compositions of these microstructures and microfabrics is dolomites and the others are siliceous minerals.

\subsection{Dolomitic microstructures}

Most of the dolomites are rhombic euhedral crystals in the dark laminae, as determined by SEM. The spherical dolomites in the dolomite crystals or on the surface of the crystals are so poorly crystallized that even part of the crystal surface was modified by those spherical morphology (Fig- ure 6). The EDAX patterns of the poorly crystallized spherical dolomites in the micron, submicron, or nanometer scale show that $\mathrm{Mg}$ content is slightly higher than $\mathrm{Ca}$ content (Figure 7). The nanoscale spherical dolomites with a $40 \mathrm{~nm}$ to $100 \mathrm{~nm}$ diameter aggregate into dolomites with diameters of $470 \mathrm{~nm}$ to $1020 \mathrm{~nm}$ in the micron, submicron, or nanometer scale. In some of the samples, poorly crystallized dolomites are found on the crystal surfaces, thereby modifying surface morphology (Figure 6(a),(b)). In the other samples, spherical dolomites are densely distributed in the crystals; these dolomites remain visible even after the crystals were cut to expose poor crystallization (Figure 6(c), (d)).

The spherical dolomites (diameter, 470-660 nm) on the crystal surface are arranged in chains. Closer observations reveal that all these micron-scale spherical dolomites are aggregated into smaller dolomites with diameters of 50-100 $\mathrm{nm}$; biofilm-like, poorly crystallized dolomites also span the dolomite crystals (Figure 6(a)). Spherical apophysis is observed on the surfaces of the dolomite crystals, a phenomenon that partially changed the morphological characteristics of the dolomite surfaces; these dolomites are distributed in the same manner as the micron-scale dolomites (Figure 6(b)). The poorly spherical nanoscale dolomites (diameter, $50-70 \mathrm{~nm}$ ) are strongly aggregated into chains, which are
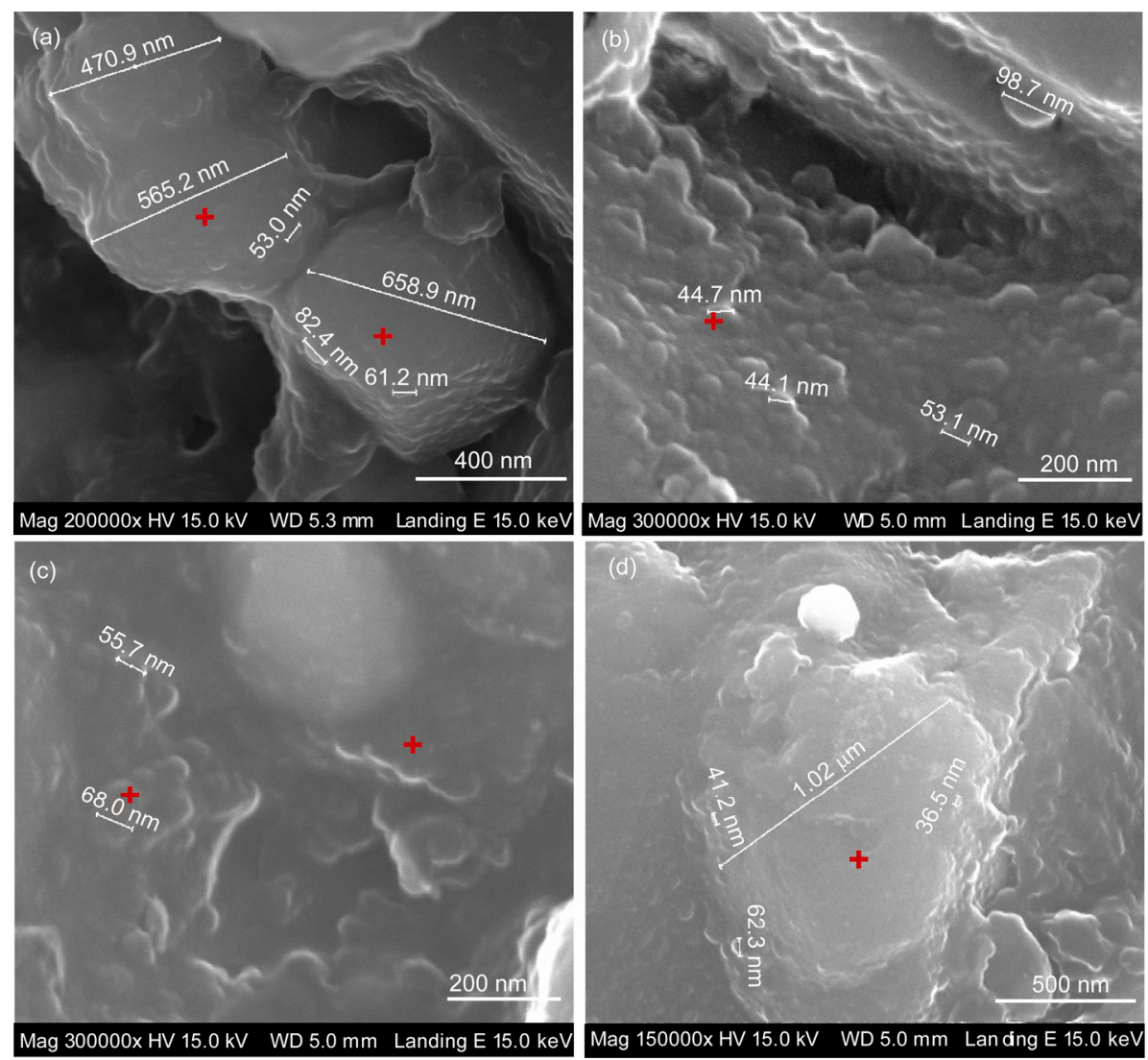

Figure 6 Photomicrographs (SEM) illustrating the characteristics of spheroidal structure dolomites. (a) The spherical dolomites on the crystal surface arranged in chains; (b) spherical apophysis partially changed the morphological characteristics of the dolomite surfaces; (c) the poorly spherical nanoscale dolomites (diameter, $50 \mathrm{~nm}$ to $70 \mathrm{~nm}$ ) strongly aggregated; (d) these aggregates approximately $1 \mu \mathrm{m}$ in diameter and comprise smaller spherical dolomites of nanometer scale. Red Crosses are spectrum spots. 




Figure 7 EDAX spectrum showing the typical composition of the dolomite crystals shown in Figure 6.

visible in the dolomite crystals (Figure 6(c)). In particular, micron-scale aggregates are present. These aggregates are approximately $1 \mu \mathrm{m}$ in diameter and comprise smaller spherical dolomites of nanometer scale. The nanometer-scale spheres are strongly distributed and aggregated around the micron-scale dolomites (Figure 6(d)).

\subsection{Siliceous microfabrics}

SEM observations reveal not only dolomitic microfabrics, but also unique siliceous microfabrics. The two types of siliceous microstructures are spherical and filamentous microtextures (Figure 8). Such microstructures are composed predominantly of $\mathrm{Si}$, with variable $\mathrm{Al}$ concentrations and a small amount of $\mathrm{Ca}$ and $\mathrm{Mg}$ (Figure 9).

A substantial amount of siliceous microfabrics resemble coccoid remains; in particular, these microfabrics show clusters of spherical pustules in the dark laminae (Figure 4(b)). The SEM results indicate dumbbell-shaped or chainlike spherical fabrics. The dumbbell-shaped spherical fabrics comprise uniform siliceous spheres with a diameter of approximately $3.7 \mu \mathrm{m}$. Other extra small siliceous spheres with a diameter of $1.2 \mu \mathrm{m}$ are connected to the dumbbellshaped fabrics, but not in a linear manner. They are instead arranged at a certain angle (Figure 8(a)). Meanwhile, some uniform spheres (diameter, $4 \mu \mathrm{m}$ ) are chained in a line and an extra sphere (diameter, $6 \mu \mathrm{m}$ ) is incorporated into the chain (Figure 8(b)).

Filamentous remains are always of micron scale, but they differ in length and diameter. Some have diameters that range from 10 to $20 \mu \mathrm{m}$, and are independent of the size of crystals, which have smooth surfaces and rarely complicat- ed structures (Figure 8(c)). Some filaments are wrapped by the same siliceous sheets (Figure 8(d)).

With regard to siliceous spherical aggregates and the arrangement of surrounding filamentous remains, which can be related to biomineralization, all the microfabrics show unique mineralized microstructures in microbial mats or biofilms. The compositions of these microfabrics also represent mineralized mucus or extracellular polymeric substances (EPS).

\section{Discussion}

The Penglaiba section was chosen for this study because it is composed of the Cambrian strata that are suitable for this type of research; the Cambrian stromatolites have wellpreserved original geochemical signals (Xie et al., 2009; Wang et al., 2011) and stromatolitic laminae (Figure 4). The strong fluorescences of dark laminae in the stromatolites (Figure 5) represent the presence of residual organic substances (Reitner and Neuweiler, 1995; Russo et al., 1997, 2000). This feature also reveals the distribution and concentration of biological and fluorescent chromophore macromolecules; examples include aromatic compounds, humic acid, and fulvic acid (vandenbroucke et al., 1985; Bertrand et al., 1986; Ramseyer et al., 1997). SEM observations show unusual microstructures in the dolomitic or silicified filamentous and bacterial remains. The distributions are dense in some regions, which is consistent with the finding that microorganisms tend to accumulate at nutrient-rich areas. These results indicate a relationship between special microfabrics and biological origins. 

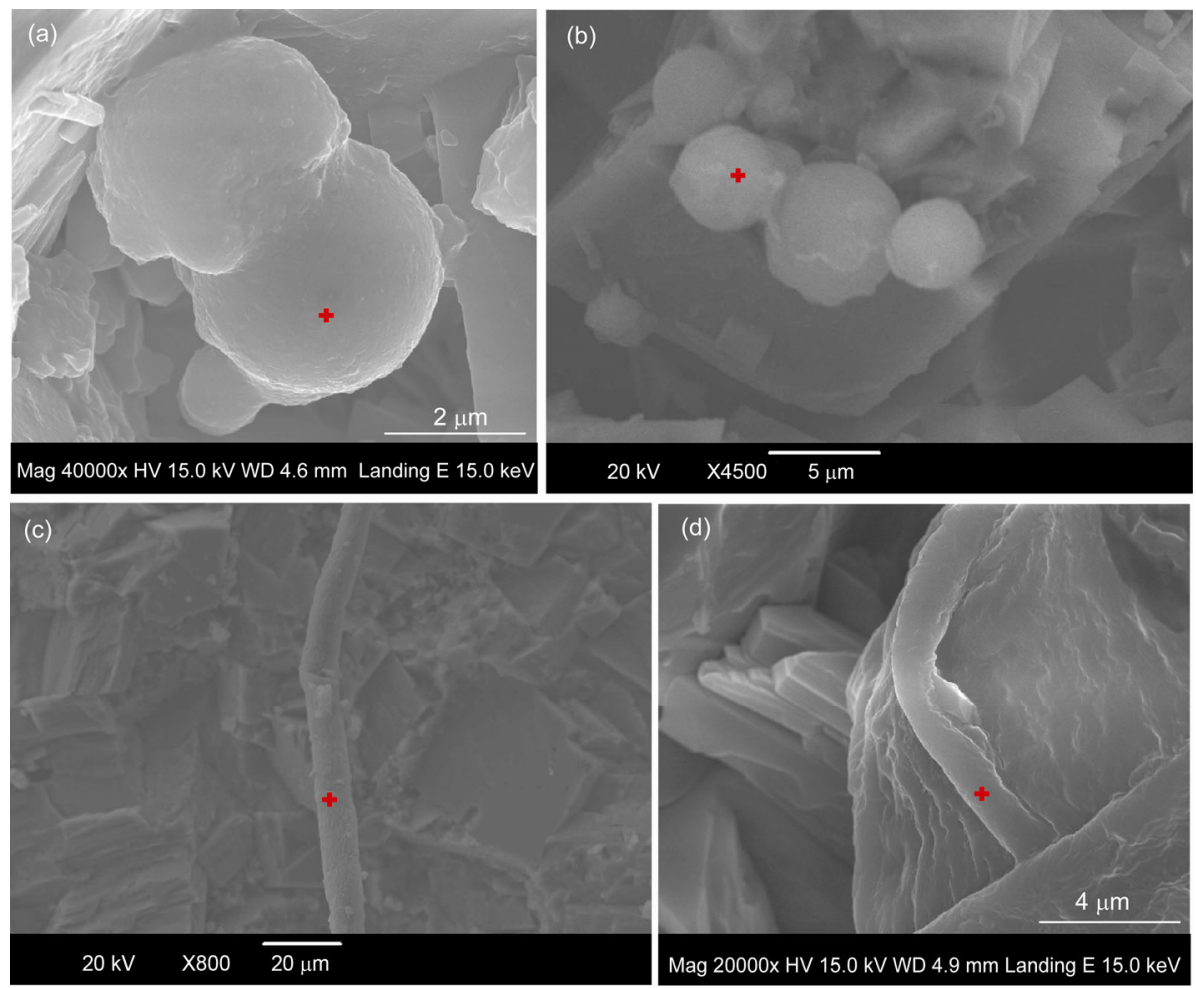

Figure 8 Photomicrographs (SEM) illustrating the characteristics of silica filaments and coccoid cells. (a) The dumbbell-shaped spherical fabrics with extra small siliceous spheres; (b) uniform spheres (diameter, $4 \mu \mathrm{m}$ ) chained in a line and an extra sphere; (c) filamentous remains independent of the size of crystals; (d) some filaments wrapped by the same siliceous sheets. Red Crosses are spectrum spots.



Figure 9 EDAX spectrum showing the typical composition of the dolomite crystals shown in Figure 8.

\subsection{EPS bonding and silicification in mineralization}

Previous studies have documented that EPS plays an important role in biogeochemical processes (Decho, 1990; Bhaskar and Bhosle, 2005). EPS is the first biofilm structure to come into contact with potential organic and inorganic metabolic substrates, predators, and antimicrobial agents/ antibiotics (Costerton et al., 1995). These substances are produced extensively by many types of bacteria, either photosynthetic autotrophic bacteria or heterotrophic bacteria. 
Among these, cyanobacteria are the most important producers in modern microbial mats (De Philippis, 1998, De Philippis et al., 2001; Stal, 2003; Richert et al., 2005). Many studies indicate that the EPS from cyanobacteria can bind ions from ambient water; such ions include calcium, magnesium, carbonate, and silica (Konhauser, 1998; SánchezNavas et al., 1998; Léveillé et al., 2000; Arp et al., 2003; Decho et al., 2005). These findings echo the silification microstructures revealed by our results (Figure 9). The EPS from many bacterial strains comprise functional groups, such as carboxylic acids ( $\mathrm{R}-\mathrm{COOH})$, hydroxyl groups $(\mathrm{R}-\mathrm{OH})$, amino groups $\left(\mathrm{R}-\mathrm{NH}_{2}\right)$, sulfate $\left(\mathrm{R}-\mathrm{O}-\mathrm{SO}_{3} \mathrm{H}\right)$, sulfonate $\left(\mathrm{R}-\mathrm{SO}_{3} \mathrm{H}\right)$, and sulfhydryl groups $(-\mathrm{SH})$, all of which can induce strong complexation between metal ions and other ions (Bianchi, 2007). However, the role of EPS in the nucleation of $\mathrm{Si}$ results from hydrogen bonding between the external residue charges of organic compounds and silicic acid (Westall et al., 1995), or form the absorption of the negative charges of Si ions by the external positive charges of functional groups (Urrutia and Beveridge, 1993). Dupraz et al. (2004) summarized the interactions between microorganisms and minerals in the hypersaline environments of the Bahamas; highly ordered EPS macromolecules facilitate the precipitation of carbonates. Some studies also suggest that certain cyanobacteria can form external layers of subcrystal proteins (Schultze-Lam et al., 1992; Schultze-Lam and Beveridge, 1994); these layers serve as nucleation centers for calcite and other minerals (Schultze-Lam and Beveridge, 1994).

A generally accepted finding is that after cell death in modern microbial mats, cells are rapidly degraded by anaerobic bacteria (Kempe and Kazmierczak, 1993; Kazmierczak et al., 1996; Kazmierczak and Iryu, 1999), but many studies have shown that even after degradation by heterotrophic bacteria, the degraded cells or EPS continue to have the capacity of constraining various ions as nucleation centers (Konhauser et al., 1994; Urrutia and Beveridge, 1994; Tazaki, 1997; Barker and Banfield, 1998; Douglas and Beveridge, 1998).

A typical hypothesis is that when bacteria are involved in carbonate precipitation, the carbonates undergo recrystallization, but the resultant products cannot clearly reveal the presence of bacterial fossils or macromolecule structures in the carbonates. Nevertheless, if silicification in microbial mats occurs at an early stage, the Miocene samples can substantially preserve cell membranes and EPS ultrastructures (Renaut et al., 1998; Konhauser et al., 2001). For example, in the modern microbial environments of the Lake Van Turkey, the Miocene lacustrine stromatolites in the Duro Basin in Spain, and the Archean formations in South Africa, EPS was partially silicified and bound with calcium and magnesium (Kazmierczak et al., 2009; Sanz-Montero et al., 2008). This result indicates that silicification can prevent carbonates from recrystallizing, thereby enabling the preservation of original signals. The silicified spheroids and filaments in our study have compositions and morphologies that are similar to those of the filaments in the stromatolites found in Lagoa Vermelha, Brazil (Spadafora et al., 2010). They are also similar to the mineralized EPS preserved in geological history (Kazmierczak et al., 2009; Sanz-Montero et al., 2008). Therefore, the silicified spheroids and filaments in the current work were preserved because EPS or mucus surrounded the produced metabolites (Westall et al., 2000).

\subsection{Origin of microbial dolomites}

Under the Earth's surface, dolomites cannot precipitate from abiotic solution, even at 1000-fold oversaturation, because of kinetic barriers (Hartman, 1982; Machel and Mountjoy, 1986; Hardie, 1987; Sibley and Gregg, 1987; Land, 1998). However, sulfate-reducing bacteria, methanogens, and moderately halophilic aerobic bacteria can mediate primary dolomite formation (Vasconcelos et al. 1995; Van Lith et al. 2003a, 2003b; Roberts et al. 2004; Sánchez-Román et al. 2009, 2011; Kenward et al. 2009; Krause et al., 2012). EPS is crucial to the nucleation process (Sánchez-Román et al. 2008; Bontognali et al., 2008, 2010). The Lake Mono in California is characterized by enhanced cyanobacterial mineralization because cyanobacteria and other types of microorganisms have a certain affinity for magnesium ions (Souza-Egipsy et al., 2005); the outer membranes of some bacteria can complex only with calcium and magnesium irons (Coughlin et al., 1983). Such features created a microenvironment favorable to dolomite formation. These characteristics may also be the drivers of spherical dolomite formation in the current study.

Microbial mats are characterized by micritic, rhombic, dumbbell-shaped, needle-shaped, and spherical fabric morphologies; these minerals are carbonates, such as aragonite, calcite, monohydrocalcite, vaterite, magnesium-calcite, and calcium-dolomite. Many studies indicate that polymeric properties (such as the abundance of acidic functional groups, water content) considerably influence the morphology and mineralogy of carbonates (Hardikar and Matijevic, 2001; Braissant et al., 2003; Chekroun et al., 2004; Bosak and Newman, 2005; Dupraz and Visscher, 2005; Ercole et al., 2007; Lian et al., 2007; Rodriguez-Navarro et al., 2007). The electrostatic binding and geometry that occurs during intermolecular interactions at inorganic-organic interfaces can control the nucleation and growth of inorganic crystals (Mann et al., 1993). Generally, these effects can reduce energy, thereby promoting nucleation on organic substances. Culture experiments have shown similar effects on the precipitation of primary dolomites (van Lith et al. 2003b; Sánchez-Román et al. 2009; Bontognali et al., 2008, 2010; Krause et al., 2012). In the present work, the poorly crystallized internal or external dolomite crystals in dark laminae of micron and submicron scales consist of nanoscale spherical dolomites with diameters of $50 \mathrm{~nm}$ to $100 \mathrm{~nm}$. Dolomites (e.g., dumbbell-shaped, linearly arranged, or irregu- 
larly aggregated dolomites) with diameters of $50 \mathrm{~nm}$ to 170 $\mathrm{nm}$ are also freely arranged (Figure 6). Nevertheless, the morphology, size, and arrangement of the dolomites are similar to those reported by Bontognali (2008), SánchezRomán et al. (2008), and Krause (2012). Bontognali (2008) reported that under anaerobic conditions, bacteria produce granular dolomites around ambient cells during the metabolic process; the dolomites are produced in this manner for self-protection. Sánchez-Román (2008) reported that two moderately halophilic aerobic bacteria, Halomonas meridiana and Virgibacillus marismortui, can produce a large number of aggregates of nanometer scale to form granular textures (nanoglobule structures); most of these aggregates have diameters of $50 \mathrm{~nm}$ to $100 \mathrm{~nm}$, and a few have diameters of $100 \mathrm{~nm}$ to $200 \mathrm{~nm}$. Therefore, the morphology, size, and distribution determined in this study and the primary dolomite precipitation revealed by culture experiments in previous studies may indicate the bacteria involved in the formation of stromatolitic dolomites. Some of these dolomites are primary dolomites and others are microbially mediated dolomites.

\section{Conclusions}

The Cambrian stromatolites in the dark laminae studied in this work are characterized by uniquely preserved attributes: (1) dolomites with 50-100 nm spherical nanostructures are aggregated into minerals of larger sphericities; (2) nanospherical dolomites of 50-170 nm diameter are densely arranged as dumbbell-shaped or chained aggregates; (3) silicified filaments, as well as dumbbell-shaped and chain arrangements, are preserved as important microstructures. The sedimentological, petrological, and geochemical data indicate that organic functional groups bond to ions, thereby ensuring high $\mathrm{Mg}$ : Ca ratios; organic substrates favor dolomite precipitation given changes in $\mathrm{pH}$, redox potential, elemental ratio, and alkalinity and saturation indices.

Silicification is a unique preservation mechanism for filaments, as well as spherical and biofilm microstructures.

The results provide evidence for the origin of the dolomites found in the stromatolites of the Tarim Basin, and elucidate the formation of ancient microbial dolomites.

This work was financially supported by the National Natural Science Foundation of China (Grant No. 41402102), Fundamental Research Funds for the Central Universities (Grant No. 2652014001), the National Science and Technology Major Project of the Ministry of Science and Technology of China (Grant No. 2011ZX05005-002-008HZ) and National Basic Research Program of China (Grant No. 2011CB201100-03). We thank Prof. Dai Yongding of the Institute of Geology and Geophysics, CAS for his help in identifying biomineralization and Prof. Hu Wenxuan, Prof. Li Chaosheng, and Dr Wang Zhiqiang of Nanjing University for their assistance in high-resolution scanning electron microscopy.

Arp G, Reimer A, Reitner J. 2003. Microbialite formation in seawater of increased alkalinity, Satonda Crater Lake, Indonesia. J Sediment Res, 73: $105-127$

Barker W W, Banfield J F. 1998. Zones of chemical and physical interaction at interfaces between microbial communities and minerals: A model. Geomicrobiol J, 15: 223-244

Bertrand P, Pittion J L, Bernaud C. 1986. Fluorescence of sedimentary organic matter in relation to its chemical composition. Org Geochem, 10: 641-647

Bhaskar P V, Bhosle N B. 2005. Microbial extracellular polymeric substances in marine biogeochemical processes. Curr Sci, 88: 45-53

Bianchi T S. 2007. Biogeochemistry of Estuaries. New York: Oxford University Press. 1-688

Bontognali T, Vasconcelos C, Warthmann R J, et al. 2008. Microbes produce nanobacteria-like structures, avoiding cell entombment. Geology, 36: 663-666

Bontognali T, Vasconcelos C, Warthmann R, et al. 2010. Dolomite Formation within microbial mats in the coastal sabkha of Abu Dhabi (United Arab Emirates). Sedimentology, 57: 824-844

Bosak T, Newman D K. 2005. Microbial kinetic controls on calcite morphology in supersaturated solutions. J Sediment Res, 75: 190-199

Bosak T, Newman D K. 2003. Microbial nucleation of calcium carbonate in the Precambrian. Geology, 31: 577-580

Braissant O, Cailleau G, Dupraz C, et al. 2003. Bacterially induced mineralization of calcium carbonate in terrestrial environments: The role of exopolysaccharides and amino acids. J Sediment Res, 73: 485-490

Buczynski C, Chafetz H S. 1991. Habit of bacterially induced precipitates of calcium carbonate and the influence of medium viscosity on mineralogy. J Sediment Res, 61: 226-233

Castanier S, Metayer-Levrel G. Le, Perthuisot J P. 1999. Ca-carbonates precipitation and limestone genesis-the microbiogeologist point of view. Sediment Geol, 126: 9-23

Chekroun K B, Rodriguez-Navarro C, Gonzalez-Munoz M T, et al. 2004. Precipitation and growth morphology of calcium carbonate induced by Myxococcus xanthus: Implications for recognition of bacterial carbonates. J Sediment Res, 74: 868-876

Chen Y Q, Zhou X Y, Zhao K D, et al. 2008. Geochemical research on Middle Cambrian red dolostones in Tarim Basin: Implications for dolostone genesis(in Chinese). Geol J China Univ, 14:583-592

Costerton J W, Lewandowski Z, Caldwell D E, et al. 1995. Microbial biofiilms. Annu Rev Microbiol, 49: 711-745

Coughlin R T, Tonsager S, McGroarty E J. 1983. Quantitation of metal cations bound to membranes and extracted lipopolysaccharide of Escherichia coli. Biochemistry, 22: 2002-2007

De Philippis R, Margheri M C, Materassi R, et al. 1998. Potential of unicellular cyanobacteria from saline environments as exopolysaccharide producers. Appl Environ Microbiol, 64: 1130-1132

De Philippis R, Sili C, Paperi R, et al. 2001. Exopolysaccharide-producing cyanobacteria and their possible exploitation: A review. J Appl Phycol, 13: 293-299

Decho A W. 1990. Microbial exopolymer secretions in ocean: Their role(s) in food webs and marine processes. Oceanogr Mar Biol Annu Rev, 28: 73-154

Decho A W, Visscher P T, Reid R M. 2005. Production and cycling of natural microbial exopolymers (EPS) within a marine stromatolite. Paleogeogr Paleoclimatol Paleoecol, 219: 71-86

Deng S C, Dong H L, Lv G, et al. 2010. Microbial dolomite precipitation using sulfate reducing and halophilic bacteria: Results from Qinghai Lake, Tibetan Plateau, NW China. Chem Geol, 278: 151-159

Douglas S, Beveridge T J. 1998. Mineral formation by bacteria in natural microbial communities. Fems Microbiol Ecol, 26: 79-88

Dupraz C, Visscher P T, Baumgartner L K, et al. 2004. Microbe-mineral interactions: Early carbonate precipitation in a hypersaline lake (Eleuthera Island, Bahamas). Sedimentology, 51: 745-765

Dupraz C, Visscher P T. 2005. Microbial lithification in marine stromatolites and hypersaline mats. Trends Microbiol, 13: 429-438

Ercole C, Cacchio P, Botta A L, et al. 2007. Bacterially induced mineralization of calcium carbonate: The role of exopolysaccharides and capsular polysaccharides. Microsc Microanal, 13: 42-50

Fairbridge R W. 1957. The dolomite question. In: Le Blanc R J, Breeding J 
G, eds. Regional Aspects of Carbonate Deposition-A Symposium Sponsored by the Society of Economic Paleontologists and Mineralogists. SEPM Spec Publ, 5:125-178

Hardie L A. 1987. Dolomitization: A critical view of some current views. J Sediment Petrol, 57: 166-183

Hardikar V V, Matijevic E. 2001. Influence of ionic and nonionic dextrans on the formation of calcium hydroxide and calcium carbonate particles. Colloid Surface A, 186: 23-31

Hartman P. 1982. On the growth of dolomite and kaolinite crystals. Neues Jahrbuch für Mineralogie, Monatshefte, 2: 84-92

Jia C Z. 1997. Tectoniccharacteristics and Petroleum, Tarim Basin, China (in Chinese). Beijing: Petroleum Industry Press. 1-438

Kazmierczak J, Coleman M L, Gruszczynski M, et al. 1996. Cyanobacterial key to the genesis of micritic and peloidal limestones in ancient seas. Acta Palaeontol Pol, 41: 319-338

Kazmierczak J, Iryu Y. 1999. Cyanobacterial origin of microcrystalline cements from Pleistocene rhodoliths and coralline algal crusts of Okierabu-jima, Japan. Acta Palaeontol Pol, 44: 117-130

Kazmierczak J, Altermann W, Kremer B, et al. 2009. Mass occurrence of benthic coccoid cyanobacteria and their role in the production of Neoarchean carbonates in South Africa. Precambrian Res, 172: 79-92

Kempe S, Kazmierczak J. 1993. Satonda Crater Lake, Indonesia: Hydrogeochemistry and biocarbonates. Facies, 28: 1-32

Kenward P A, Goldstein R H, González L A, et al. 2009. Precipitation of low-temperature dolomite from an anaerobic microbial consortium: The role of methanogenic Archaea. Geobiology, 7: 556-565

Konhauser K O. 1998. Diversity of bacterial iron mineralization. Earth-Sci Rev, 43: 91-121

Konhauser K O, Phoenix V R, Bottrell S H, et al. 2001. Microbial-silica interactions in Icelandic hot spring sinter: Possible analogues for some Precambrian siliceous stromatolites. Sedimentology, 48: 415-433

Konhauser K, Schultze-Lam S, Ferris F G, et al. 1994. Mineral precipitation by epilithic biofilms in the Speed River, Ontario, Canada. Appl Environ Microbiol, 60: 549-553

Krause S, Liebetrau V, Gorb S N, et al. 2012. Microbial nucleation of Mg-rich dolomite in exopolymeric substances under anoxic modern seawater salinity: New insight into an old enigma. Geology, 40: 587-590

Land L S. 1998. Failure to precipitate dolomite at 25 degrees C from dilute solution despite 1000-fold oversaturation after 32 years. Aquat Geochem, 4: 361-368

Léveillé R J, Fyfe W S, Longstaffe F J. 2000. Geomicrobiology of carbonate-silicate microbialites from Hawaian basaltic sea caves. Chem Geol, 169: 339-355

Lian B, Hu Q, Chen J, et al. 2007. Carbonate biomineralization induced by soil bacterium Bacillus megaterium. Geochim Cosmochim Acta, 70: 5522-5535

Lippmann F. 1973. Sedimentary Carbonate Minerals. New York: SpringerVerlag. 1-228

Liu L, Zhu J Q, You X L, et al. 2012. Sedimentary microfacies of the Middle-Upper Cambrian dolostone in Keping area, Tarim Basin (in Chinese). J Paleogeogr, 14: 33-43

Machel H G, Mountjoy E W. 1986. Chemistry and environments of dolomitization a reappraisal. Earth-Sci Rev, 23: 175-222

Mann S, Douglas D A, Didymus J M, et al. 1993. Crystallization at inorganic-organic interfaces: Biominerals and biomimetic synthesis. Science, 261: 1286-1292

McKenzie J A, Vasconcelos C. 2009. Dolomite Mountains and the origin of the dolomite rock of which they mainly consist: Historical developments and new perspectives. Sedimentology, 56: 205-219

Ramseyer K, Miano T M, D'Orazio V, et al. 1997. Nature and origin of organic matter in carbonates from speleothems, marine cements and coral skeleton. Org Geochem, 26: 361-378

Reitner J, Neuweiler F. 1995. Mud mounds: A polygenic spectrum of finegrained carbonate buildups. Facies, 32: 1-70

Renaut R W, Jones B, Tiercelin J J. 1998. Rapid in situ silicification of microbes at Loburu hot springs, Lake Bogoria, Kenya rift Valley. Sedimentology, 45: 1083-1103

Richert L, Golubic S, Le Guedes R, et al. 2005.Characterization of ex- opolysaccharides produced by cyanobacteria isolated from Polynesian microbial mats. Curr Microbiol, 5: 379-384

Roberts J A, Bennett P C, Gonzalez L A, et al. 2004. Microbial precipitation of dolomite in methanogenic groundwater. Geology, 32: 277-280

Rodriguez-Navarro C, Jimenez-Lopez C, Rodriguez-Navarro A, et al. 2007. Bacterially mediated mineralization of vaterite. Geochim Cosmochim Acta, 71: 1197-1213

Russo F, Mastandrea A, Stefani M, Neri C. 2000. Carbonate facies dominated by syndepositional cements: A key component of Middle Triassic platforms. The Marmolada case history (Dolomites, Italy). Facies, 42: 211-226

Russo F, Neri C, Mastandrea A, et al. 1997. The mud-mound nature of the Cassian platform margins of the Dolomites. A case history: The Cipit Boulders from Punta Grohmann (Sasso Piatto Massif, Northern Italy). Facies, 36: 25-36

Sánchez-Navas A, Martín-Algarra A, Nieto F. 1998. Bacterially-mediated authigenesis of clays in phosphate stromatolites. Sedimentology, 45: 519-533

Sánchez-Román M, McKenzie J A, Wagener R A, et al. 2011. Experimentally determined biomediated $\mathrm{Sr}$ partition coefficient for dolomite: Significance and implication for natural dolomite. Geochim Cosmochim Acta, 75: 887-904

Sánchez-Román M, Vasconcelos C, Schmid T, et al. 2008. Aerobic microbial dolomite at the nanometer scale: Implications for the geologic record. Geology, 36: 879-882

Sánchez-Román M, Vasconcelos C, Warthmann R, et al. 2009. Microbial dolomite precipitation under aerobic conditions: Results from Brejo do Espinho Lagoon (Brazil) and culture experiments. In Swart P K, Eberli G P, McKenzie J A, eds. Perspectives in Carbonate Geology: A Tribute to the Career of Robert Nathan Ginsburg. IAS Spec Publ, 41:167-178

Sanz-Montero M E, Sanz-Montero J P, Rodríguez-Aranda M A, et al. 2008. Dolomite-silica stromatolites in Miocene lacustrine deposits from the Duero Basin, Spain: The role of organotemplates in the precipitation of dolomite. Sedimentology, 55:729-750

Schultze-Lam S, Beveridge T J. 1994. Nucleation of celestite and strontianite on a cyanobacterial S-layer. Appl Environ Microbiol, 60: 447-453

Schultze-Lam S, Harauz G, Beveridge T J. 1992. Participation of a cyanobacterial S-layer in fine-grain mineral formation. J Bacteriol, 174: 7971-7981

Schultze-Lam S, Fortin D, Davis B S, et al. 1996. Mineralization of bacterial surfaces. Chem Geol, 132: 171-181

Sibley D F, Gregg J M. 1987. Classification of dolomite rock textures. J Sediment Petrol, 57: 967-975

Souza-Egipsy V, Wierzchos J, Ascaso C, et al. 2005. Mg-silica precipitation in fossilization mechanisms of sand tufa endolithic microbial community, Mono Lake (California). Chem Geol, 217: 77-87

Spadafora A, Perri E, Mckenzie J, et al. 2010. Microbial biomineralization processes forming modern $\mathrm{Ca}: \mathrm{Mg}$ carbonate stromatolites. Sedimentology, 57: 27-40

Stal L J. 2003. Microphytobenthos, their extracellular polymeric substances, and the morphogenesis of intertidal sediments. Geomicrobiol J, 20: $463-478$

Sun S. 2005. Sedimentology in China: Perspectives and suggestions (in Chinese). Earth Sci Front, 12: 3-10

Tazaki, K. 1997. Biomineralization of layer silicates and hydrated Fe/Mn oxides in microbial mats: An electron microscopical study. Clay Clay Min, 45: 203-212

Tucker M E, Wright V P. 1990. Carbonate Sedimentology. Oxford: Blackwell Scientific Publications. 482

Urrutia M M, Beveridge T J. 1994. Formation of fine-grained silicate minerals and metal precipitates by a bacterial surface (Bacillus subtilis) and the implications in the global cycling of silicon. Chem Geol, 116: 261-280

Urrutia M M, Beveridge T J. 1993. Mechanism of silicate binding to the bacterial cell wall in Bacillus subtilis. J Bacteriol, 175: 1936-1945

van Lith Y, Warthmann R, Vasconcelos C, et al. 2003a. Microbial fossilization in carbonate sediments: A result of the bacterial surface involvement in dolomite precipitation. Sedimentology, 50: 237-245

van Lith Y, Warthmann R, Vasconcelos C, et al. 2003b. Sulphate-reducing bacteria induce low-temperature $\mathrm{Ca}$-dolomite and high $\mathrm{Mg}$-calcite for- 
mation. Geobiology, 1: 71-79

vanDenbroucke M, Pelet R, Debyser Y. 1985. Geochemistry of humic substances in marine sediments. In: Aiken G R, McKnight D M, Wershaw R L, et al., eds. Humic Substances in Soil, Sediment, and Water, Geochemistry, Isolation and Characterization. New York: John Wiley and Sons. 249-273

Vasconcelos C , McKenzie J A, Bernasconi S, et al. 1995. Microbial mediation as a possible mechanism for natural dolomite formation at low temperatures. Nature, 377: 220-222

Vasconcelos C, McKenzie J A. 1997. Microbial mediation of modern dolomite precipitation and diagenesis under anoxic conditions (Lagoa Vermelha, Rio de Janeiro, Brazil). J Sediment Res, 67: 378-390

Visscher P T, Stolz J F. 2005. Microbial mats as bioreactors: Populations, processes, and products. Paleogeogr Paleoclimatol Paleoecol, 219: 87-100

Wang X L, Hu W X, Yao S P, et al. 2011. Carbon and strontium isotopes and global correlation of Cambrian Series 2-Series 3 carbonate rocks in the Keping area of the northwestern Tarim Basin, NW China. Mar Petrol Geol, 28: 992-1002

Warthmann R, van Lith Y, Vasconcelos C, et al. 2000. Bacterially induced dolomite precipitation in anoxic culture experiments. Geology, 28: 1091-1094

Westall F, Boni L, Guerzoni M E. 1995. The silicification of microorgan- isms. Palaeontology, 38: 495-528

Westall F, Steele A, Toporski J, et al. 2000. Polymeric substances and biofilms as biomarkers in terrestrial materials: Implications for extraterrestrial samples. J Geophys Res, 105: 511-527

Wright D T, Wacey D. 2005. Precipitation of dolomite using sulphatereducing bacteria from the Coorong Region, South Australia: Significance and implications. Sedimentology, 52: 987-1008

Wright D T. 1999. The role of sulphate-reducing bacteria and cyanobacteria in dolomite formation in distal ephemeral lakes of the Coorong region, South Australia. Sediment Geol, 126: 147-157

Xie X M, Hu W X, Wang X L, et al. 2009. Sedimentary sequences in Keping area, Xinjiang: Constraints from carbon and oxygen isotope compositions of Cambrian to Ordovician carbonate rocks (in Chinese). Geochimica, 38: 75-88

You X L, Sun S, Zhu J Q, et al. 2011. Progress in the study of microbial dolomite model (in Chinese). Earth Sci Front, 18: 52-64

You X L, Sun S, Zhu J Q, et al. 2013. Microbially mediated dolomite in Cambrian stromatolites from the Tarim basin, northwest China: Implications for the role of organic substrate on dolomite precipitation. Terra Nova, 25: 387-395

Zhu J Q, Wu S Q, Wang G X, et al. 2008. Types and porosity characteristics of the Cambrian-Ordovician dolostones in Tarim basin (in Chinese). Earth Sci Front, 15: 67-79 